\title{
Countries three Wise Men: Sustainability, Innovation, and Competitiveness
}

\author{
Luis Miguel Fonseca ${ }^{1}$, Vanda Marlene Lima² \\ ${ }^{1}$ ISEP-IPP, School of Engineering, Polytechnic Institute of Porto (Portugal) \\ ${ }^{2}$ School of Technology and Management of Felgueiras, Polytechnic Institute of Porto (Portugal) \\ Imf@isep.ipp.pt,vlima@esttg.ipp.pt
}

Received: May 2015

Accepted: September 2015

\begin{abstract}
:
Purpose: The studies on links between sustainability, innovation, and competitiveness have been mainly focused at organizational and business level. The purpose of this research is to investigate if there is a correlation between these three variables at country level. Using international well recognized rankings of countries sustainability, innovation, and competitiveness, correlation analysis was performed allowing for the conclusion that there are indeed high correlations (and possible relationships) between the three variables at country level.
\end{abstract}

Design/methodology/approach: Sustainability, innovation, and competitiveness literature were reviewed identifying a lack of studies examining these three variables at country level. Three major well recognized indexes were used to support the quantitative research: The World Economic Forum (2013) Sustainability-adjusted global competitiveness index, the Global Innovation Index (2014) issued by Cornell University, INSEAD, and WIPO and the IMD World Competitiveness Yearbook (2014).

After confirming the distributions normality, Pearson correlation analysis was made with results showing high linear correlations between the three indexes. 
Findings: The results of the correlation analysis using Pearson correlation coefficient (all correlation coefficients are greater than 0.73 ) give a strong support to the conclusion that there is indeed a high correlation (and a possible relationship) between social sustainability, innovation and competitiveness at country level.

Research limitations/implications: Further research is advisable to better understand the factors that contribute to the presented results and to establish a global paradigm linking these three main constructs (social sustainability, innovation, and competitiveness). Some authors consider that these measurements are not fully supported (e.g. due to different countries standards), however, it is assumed these differing underlying methodological approaches, by being used in conjunction, can be considered as a set of reliable and useful performance indicators.

Practical implications: The results highlight the simultaneous relationship between social sustainability, innovation and competitiveness superior performance and the need to take that these considerations into business and operating models.

Social implications: This research suggests that sustainability and innovation policies, strategies and practices are relevant for countries competitiveness and should be promoted particularly in countries ranked low on sustainability and innovation global scoring indexes.

Originality/value: This is one of the few studies addressing the relationships between sustainability, innovation and competitiveness at country level.

Keywords: sustainability, corporate social responsibility, innovation, countries competitiveness

\section{Introduction}

The world has seen considerable changed in the last decades with an increased mobility and access to information and a growing economic and financial inter-dependence. At the same time, we witness a range of global issues, like environmental protection, health improvement and fight against poverty.

Humanity faces today problems of global nature and complexity:

- In the year 2010, world population reached 7 thousand million (billion) people and continues to growth which means world population can reach 9.5 thousand million (billion) people by 2050 (United Nations, 2014). 
- In 2050 (United Nations, 2014) 86.4\% of human beings will live in less developed regions.

- Reducing both poverty and people's vulnerability to falling into poverty must be a central objective of the post-2015 agenda (United Nations, 2014). Despite recent progress in poverty reduction, more than 2.2 billion people are either near or living in multidimensional poverty.

- According to the United Nations 2014 Human Development Report, climate change remains a growing potential to undermine progress in human development generating rising temperatures, less agriculture outputs, lack of water supplies, increase of the ocean levels, health problems, negative impacts on biodiversity, etc. As stated by the United Nations (2014), environmental degradation and climate change threaten the long-term survival of humanity.

In order to overcome these problems and take into account the present political, economic, social, technological, environmental and legal frameworks there is a must for a development model that takes into account economic, social and environmental perspectives and considers the adoption of a multi-stakeholder and long term view for achieving sustainable organizational success.

Due to these rising problems, concepts like Sustainable Development (Brundtland, 1987) and Triple Bottom Line (Elkington, 1997) have become common leading to stronger pressure on business to act in a more transparent way and to search for the creation of economic value, while respecting the environment and contributing to social justice and equity. Researchers have been studying the relationships between Sustainability / Corporate social responsibility and competitiveness either from a normative/moral approach (the right thing to do, since businesses have obligations not only to their shareholders but also to multiple stakeholders, including overall society) or by a strategic/instrumental approach (increase of firms competitiveness).

Although the strategic value of CSR for nation's competitiveness has been addressed by European Union (2011), literature review supports the conclusion that the relationships between sustainability/corporate social responsibility and competitiveness have been mainly studied at organizational and business level, with only a few studies addressing these issues at country level (Stevens, Neelankavil, Mendonza \& Shankar, 2012; Boulouta \& Pitelis, 2014).

Since Schumpeter (1942) that innovation is considered both a determinant of a nation competitiveness leading to the opportunity to study possible relationships with sustainability and competitiveness. 
This work aims to research the relationships between sustainability, innovation, and competitiveness at country level, contributing to the knowledge on the relationships between these three variables.

Three major international indexes that have achieved international visibility have been used to for testing possible correlations at country level: the World Economic Forum (2013) Sustainability-adjusted global competitiveness index, the Global Innovation Index 2014 and the IMD World Competitiveness Yearbook (2014).

By using a quantitative approach, the research objectives have taken into consideration the objects being studied and the literature review was focused on Sustainability, Innovation and competitiveness.

The results and conclusions are in support of the propositions presented that there is indeed a high positive relationship between social sustainability, innovation and competitiveness when the unit of analysis is country adding new contributions to this research field.

\section{Sustainability, Innovation, and Competitiveness Literature Review}

\subsection{Sustainability}

"Sustainable development is development that meets the needs of the present without compromising the ability of future generations to meet their own needs" in the definition of the Brundtland Commission Report (1987) has appeared as an overall response for the concerns expressed in the United Nations 2014 Human Development Report (United Nations, 2014). This implies the simultaneous search for profitable economic development, social progress and equity and respect for the environment while creating value for shareholders, customers, workers and the society at large. This also requires a multidisciplinary and systemic approach since the global nature of the issues require that economic actors, governments, public and private organizations and citizens be actors in this process. Over the years, there has been much debate about what sustainability means and about what measures can track sustainable progress or the lack of it. In 2012, the United Nations Conference on Sustainable Development in Rio took a broad view that sustainable progress must cover all three dimensions that affect people's life chances social, economic and environmental. Within this view, Sustainable Development is a concept at global and intergovernmental level; Social Responsibility is at organizational level and frames its contributions for sustainability (European Commission, 2002; ISO 26000:2010 International Standard, Guidance on social responsibility).

However, some academic authors have been presenting alternative definitions of CSR and sustainability, e.g., Parhankaugas, McWilliams and Shrader (2014) offer a contrasting view between CSR and Sustainability: both focused on social and ecological good, but with CSR 
aiming to competitive advantages through marginal improvements, Bottom of Pyramid (BoP) as consumers and focus on current stakeholder needs while sustainability is focused on durable competitive advantages through revolutionary changes, BoP as producers and focus on current, distant and future trends.

So, although there is no consensus concerning the concept of CSR and sustainability, the literature review allows us to conclude that most definitions take into consideration economic, social and environmental dimensions. Conceptually, both sustainable development and social responsibility aim for the simultaneous search of economic profitable development with social progress and equity and respect for natural environment, generating value for shareholders, customers, workers, partners and society in general.

Within this study, expressions like CSR (corporate social responsibility) and sustainability are used as "umbrella constructs" as presented by Hirsch and Levin's (1999, pp. 200) as "a broad concept or idea used loosely to encompass and account for a broad set of diverse phenomena" (Gond and Crane, 2010). This could include concepts like corporate citizenship (Carroll, 1998), business ethics (Bowie 1999), stakeholder orientation (Freeman, 1984), triple bottom line (Elkington, 1997) and creating shared value (Porter \& Kramer, 2011). This is line with the 2012 United Nations Conference on Sustainable Development in Rio: sustainable progress must cover all three dimensions that affect people's life chances (social, economic and environmental).

The theoretical framework for this research is based on Stakeholder Theory (Freeman, 1984; Donaldson \& Preston, 1995; Mitchell, Agle \& Wood, 1997) that focus on the importance of a firm's relationships with critical stakeholders that may lead to better performance, as organizations that integrate business and societal considerations create value for their stakeholders.

It has also been recognized that ethical behaviours (normative orientation) can result into significative competitive advantage (instrumental orientation) as organizations develop relationships of trust and collaboration with stakeholders originating improvement on the competitive performance of the organization. Stakeholder Theory by Freeman (1984), Carroll (1979), McWilliams and Siegel (2001) and Schwartz and Carrol (2003), focus on the importance of a firm's relationships with critical stakeholders that may lead to better performance, as organizations that integrate business and societal considerations create value for their stakeholders.

Although not yet unanimous, studies have found that the relationship between stakeholders satisfaction and organizational sustainable growth and success is indeed influenced by the importance of a firm's relationships with critical stakeholders that may lead to better performance, as organizations while integrating business and societal considerations create value for their stakeholders (Fonseca, 2012). Reviews of the empirical literature and meta- 
analysis studies have confirm a positive link between financial and social performance (Margolis \& Walsh, 2003; Orlitzky, Schmidt \& Rynes, 2003; van Beurden \& Gossling, 2008; Rodríguez, Gallego \& Pérez, 2014) although some methodological concerns have been raised (Margolis \& Walsh, 2003).

But this discussion has been carried on mainly at the firm level and has not been adequately addressed at the macroeconomic level (EC 2008). Only a few authors (e.g. MacGillivray Sabapathy \& Zadek, 2003; Zadek, 2006; Stevens et al., 2012; Boulouta \& Pitelis, 2014) have studied the links between CSR and national competitiveness concluding that CSR can make a significative contribution to countries competitiveness.

For this research, the Social sustainability pillar performance of countries was measured with the World Economic Forum (2013) Sustainability-adjusted global competitiveness index (http://www.weforum.org/content/pages/sustainable-competitiveness, accessed 2014.12.19).

\subsection{Innovation}

Innovation is considered both a key determinant of a nation's competitiveness (Schumpeter 1942; Penrose, 1959; Hall \& Soskice, 2001) and a key determinant of firm performance (Mone, McKinley \& Barker, 1998). For Schumpeter, innovation is doing things in a different way: can be a new good or a new quality of a good; a new method of production; a new market; a new source of supply; or a new organizational structure.

OECD/Eurostat Oslo Manual (pp. 46, 2005) considers a broad definition of innovation encompassing a wide range of possible innovations: "Innovation is the implementation of a new or significantly improved product (goods or services), or process, a new marketing method, or a new organizational method in business practices, workplace organization or external production".

There are many loose applications of the term 'innovation', sometimes considered as creativity, knowledge, or change. For this research we will consider that innovation is both a process and an outcome and is related to the production, adoption, assimilation or exploitation of a valueadded novelty either at macro (country) or micro (organization and firm) level.

The Global Innovation Index 2014 is issued by Cornell University, INSEAD, and WIPO (https://www.globalinnovationindex.org/userfiles/file/reportpdf/GII-2014-v5.pdf, a c c e s s e d 2014.12.19) is widely used to measure countries innovation scoring. The model includes eighty-one (81) indicators, which fall within the following three categories: fifty-six (56) variables of hard data, twenty (20) composite indicators from international agencies and five (5) survey questions from the World Economic Forum's Executive Opinion Survey (EOS). 
Authors like Zadek (2006) have discussed how CSR can foster innovation at a macro level. Also improved stakeholder relations can promote co creation opportunities leading to further innovation and shared value (Porter \& Kramer, 2011).

\subsection{Competitiveness}

For the Organization for Economic Cooperation and Development (OECD) country's competitiveness is defined as "The degree to which a country can, under free and fair market condition, produces goods and services which meet the test of international markets, while simultaneously maintaining and expanding the real incomes of its people in the long term."The World Economic Forum (WEF) defines competitiveness as: 'the set of institutions, policies and factors that determine the level of productivity of a country' (Schwab, 2009, pp. 4). The European Commission has defined competitiveness atthe macro-economic level 'as a sustained rise in the standards of living' (EC, 2008, pp. 15). Accordingly to Aiginger (2006) based on literature review, country competitiveness can be defined as 'the ability of a country or location to create welfare' (2006, pp. 161), which incorporates both an outcome of competitiveness and the analysis of factors that produce the outcome.

The definition of competitiveness also incorporates a benchmark for comparing the performance as it is the case of the IMD World Competitiveness Yearbook (WCY), available since 1989 that is one of the most recognized survey studies on nation competitiveness (http://www.imd.org/news/2014-World-Competitiveness.cfm, accessed 2014.12.19). It ranks countries according to their ability to attain economic prosperity. WCY defines a nation's competitiveness as, "a measurement of each nation's ability to create and maintain an environment that sustains more value creation for its enterprises and more prosperity for its people" and this definition was adopted within this research. Accordingly to WYC nation competitiveness cannot be determined by GDP alone since political, social and cultural issues must also be taken into consideration. The WCY methodology considers four main countries competitiveness factors with twenty (20) sub-factors: economic performance, government efficiency, business efficiency and infrastructure. Both quantitative and qualitative (executive surveys) variables are used generating overall rankings for countries that are simple to interpret and frequently used to access a country's competitiveness. This index was used in this wok to measure the competitiveness of a country.

Some critics concerning the use of WCY should be acknowledge, as the difficulties in gathering reliable data for the considerable list of variables included in the index that sometimes countries find hard to report (Oral \& Chabchoub, 1996). 


\section{Hypotheses and Methodology}

This paper researches the relationships between social sustainability, innovation, and competitiveness by presenting the following hypothesis:

Ha: Is there a relationship between social sustainability, innovation and competitiveness?

Three major international indexes that have achieved international visibility have been used to test Ha:

- The Social sustainability pillar performance of countries was measured with the World Economic Forum (2013) Sustainability-adjusted global competitiveness index (http://www.weforum.org/content/pages/sustainable-competitiveness, a c c e s s e d 2014.12.19).

- The Global Innovation Index 2014 is issued by Cornell University, INSEAD, and WIPO (The Global Innovation Index 2014: The Human Factor in innovation, Fontainebleau, Ithaca, and Geneva) and was used to measure countries innovation scoring.

- The IMD World Competitiveness Yearbook 2014 was used as a measure of countries competitiveness. The 2014 report assesses the competitiveness of 60 countries based on 338 criteria. Two-thirds of these are derived from statistical indicators (competitiveness as it is "measured ") and one-third from the perceptions of opinion leaders (competitiveness as it is "perceived").

Although there is some controversy concerning the reliability of these indexes (e.g., Porter \& Kramer, 2006), while not stating that these measurements are $100 \%$ supported, it is assumed that differing underlying methodological approaches, by being used in conjunction, can be considered as a set of reliable and useful performance indicators. A sample of fifty-four countries worldwide that were present simultaneously on the three indexes was used for the research.

The research hypothesis $\mathrm{Ha}$ (is there a relationship between social sustainability, innovation, and competitiveness) was tested with correlation analysis between the three international indexes using Pearson correlation coefficient. 


\section{Results}

We started by testing test the normality of the samples trough Kolmogorov-Smirnov Test. In case the data follows a normal distribution we can use Pearson correlation coefficient and in case this does not occur we should use correlation coefficient Spearman Rho. Both correlation coefficients, measure the intensity of the relationship between ordinal variables (Spearman Rho does not require that data provides from normal distributions) and vary between - 1 e 1 . As near the values are from these extremes the stronger is the linear association between the variables. For both correlation coefficients the sign indicates the direction of the association between $X$ (the independent variable) and $Y$ (the dependent variable). If $Y$ tends to increase when $X$ increases, the correlation coefficient is positive. If $Y$ tends to decrease when $X$ increases, the correlation coefficient is negative. If the value is zero this means there is no linear relationship between the variables.

K-S normality test was used with the following hypotheses and the results are presented in Table 1 bellow:

Ho: the variables follow normal distributions.

H1: the variables do not follow normal distributions.

\begin{tabular}{|c|c|c|c|c|}
\hline & & $\begin{array}{c}\text { Social } \\
\text { Sustainability } \\
\text { Scoring }\end{array}$ & $\begin{array}{l}\text { Innovation } \\
\text { Scoring }\end{array}$ & $\begin{array}{l}\text { IMD } 2014 \\
\text { Scoring }\end{array}$ \\
\hline \multicolumn{2}{|l|}{$\mathbf{N}$} & 54 & 54 & 54 \\
\hline \multirow{2}{*}{ Normal Parameters ${ }^{\mathbf{a}, \mathbf{b}}$} & Mean & 4.946338 & 46.098 & 63.870814 \\
\hline & Std. Deviation & .8206969 & 9.8152 & 15.0545684 \\
\hline \multirow{3}{*}{ Most Extreme Differences } & Absolute & .087 & .124 & .089 \\
\hline & Positive & .087 & .124 & .089 \\
\hline & Negative & -.075 & -.098 & -.074 \\
\hline \multicolumn{2}{|l|}{ Kolmogorov-Smirnov Z } & .642 & .913 & .657 \\
\hline \multicolumn{2}{|l|}{ Asymp. Sig. (2-tailed) } & .804 & .376 & .780 \\
\hline
\end{tabular}

a. Test distribution is Normal.

b. Calculated from data.

Table 1. One-Sample Kolmogorov-Smirnov Test

The significance levels associated with Kolmogorov-Smirnov test are all greater than 0,05 , so we cannot reject the null hypotheses. Conclusion is all three distributions are normal so we can use Pearson Correlation coefficient to test Ha. 
The results of Pearson correlation coefficient are presented in Table 2:

\begin{tabular}{|c|c|c|c|c|}
\hline & & $\begin{array}{l}\text { Social Sustainability } \\
\text { Scoring }\end{array}$ & $\begin{array}{l}\text { Innovation } \\
\text { Scoring }\end{array}$ & IMD 2014 Scoring \\
\hline \multirow{3}{*}{$\begin{array}{l}\text { Social } \\
\text { Sustainability } \\
\text { Scoring }\end{array}$} & Pearson Correlation & 1 & $.860^{* *}$ & $.736^{* *}$ \\
\hline & Sig. (2-tailed) & & .000 & .000 \\
\hline & $\mathbf{N}$ & 54 & 54 & 54 \\
\hline \multirow{3}{*}{$\begin{array}{l}\text { Innovation } \\
\text { Scoring }\end{array}$} & Pearson Correlation & $.860^{* *}$ & 1 & $.832^{* *}$ \\
\hline & Sig. (2-tailed) & .000 & & .000 \\
\hline & $\mathbf{N}$ & 54 & 54 & 54 \\
\hline \multirow{3}{*}{$\begin{array}{l}\text { IMD } 2014 \\
\text { Scoring }\end{array}$} & Pearson Correlation & $.736^{* *}$ & $.832^{* *}$ & 1 \\
\hline & Sig. (2-tailed) & .000 & .000 & \\
\hline & $\mathbf{N}$ & 54 & 54 & 54 \\
\hline
\end{tabular}

**. Correlation is significant at the 0.01 level (2-tailed).

Table 2. Pearson correlation coefficient between Social Sustainability Scoring, Innovation Scoring, and IMD 2014 Scoring

These conclusions are quite relevant: there is indeed a high correlation between social sustainability, innovation and world competitiveness (unit of the analysis "country"). Moreover, if we study the Top Ten List of the three indexes we can notice that there 5 countries are simultaneously on the three indexes Top Ten and 6 countries are simultaneously on two indexes Top Ten. Nordic and Central European countries plus some Anglo-Saxon countries excel on these composed indexes performance, as shown in Table 3:

\begin{tabular}{|l|r|l|r|l|r|}
\hline \multicolumn{1}{|c|}{ Country } & $\begin{array}{c}\text { Social Sustainability } \\
\text { Scoring }\end{array}$ & \multicolumn{1}{c|}{ Country } & $\begin{array}{c}\text { Innovation } \\
\text { Scoring }\end{array}$ & \multicolumn{1}{c|}{ Country } & $\begin{array}{c}\text { IMD 2014 } \\
\text { Scoring }\end{array}$ \\
\hline Norway & 6.37 & Switzerland & 64.8 & USA & 100.00 \\
\hline Switzerland & 6.31 & United Kingdom & 62.4 & Switzerland & 92.42 \\
\hline Netherlands & 6.27 & Sweden & 62.3 & Sweden & 85.83 \\
\hline Austria & 6.22 & Finland & 60.7 & Germany & 85.78 \\
\hline Denmark & 6.16 & Netherlands & 60.6 & Canada & 85.43 \\
\hline Germany & 6.06 & United States & 60.1 & Denmark & 84.04 \\
\hline Finland & 6.05 & Denmark & 57.5 & Norway & 83.29 \\
\hline Iceland & 5.95 & Ireland & 56.7 & Malaysia & 82.09 \\
\hline New Zealand & 5.90 & Canada & 56.1 & Netherlands & 81.14 \\
\hline Australia & 5.87 & Germany & 56.0 & Ireland & 80.36 \\
\hline Belgium & 5.80 & Norway & 55.6 & United Kingdom & 79.81 \\
\hline
\end{tabular}

Table 3. Top Ten Countries of the 3 Performance Indexes

These conclusions do come into support of hypotheses $\mathrm{Ha}$, that there is indeed a correlation (and a possible relationship) between social sustainability, innovation and competitiveness, at least when the analysis is made at country level. 


\section{Discussion and Conclusions}

The results of the correlation analysis using Pearson correlation coefficient (all correlation coefficients are greater than 0.73 ) give a strong support to the conclusion that there is indeed a correlation (and a possible relationship) between social sustainability, innovation, and competitiveness. If Spearman is between 0.7 and 0.89 we can state that the linear association between the two variables is high (Pestana \& Gageiro, 2008). Moreover, the Top Ten List of countries simultaneously on the international indexes also supports this conclusion.

The results are in line with previous studies:

- CSR can make a significative contribution to countries competitiveness as advanced by MacGillivray et al. (2003), Zadek (2006), Stevens et al. (2012) and Boulouta and Pitelis (2014) that have studied the links between CSR and national competitiveness.

- The results also support innovation as a key determinant of a nation's competitiveness in line with the works of Schumpeter (1942), Penrose (1959), Hall and Soskice (2001) and the positive relations between CSR and innovation (Zadek, 2006; Porter \& Kramer, 2011).

\section{Theoretical and Practical Contributions}

Major contributions of this work are the need to be aware of the simultaneous relationship between social sustainability, innovation and competitiveness superior performance and to take these considerations into business and operating models. Despite limitations, our work contributes towards the critical question of measuring the relationships between sustainability, innovation and countries competitiveness. It provides support for the strategic view of sustainability / CSR and innovation for delivering value for business and society and for improving country competitiveness.

Our findings can be important both for public policy and managerial practice, as they suggest that sustainability and innovation policies, strategies and practices are relevant for countries competitiveness and should be promoted specially in countries ranked low on sustainability and innovation global scoring indexes.

It is expected this research can contribute to further work on these fields with the purpose of gathering further knowledge on the relationship between sustainability/CSR, innovation and national competitiveness. 


\section{Limitations and Suggestions for Future Work}

There are opportunities for further research to better understand the factors that contribute to the presented results and to establish a global paradigm linking these three main constructs (social sustainability, innovation and competitiveness). Also there is some controversy concerning the reliability of the indexes used in this research.

\section{References}

Aiginger, K. (2006). Competitiveness: From a dangerous obsession to a welfare creating ability with positive externalities. Journal of Industry, Competition and Trade, 6, 161-177. http://dx.doi.org/10.1007/s10842-006-9475-6

Boulouta, I., \& Pitelis, C.N. (2014). Who Needs CSR? The Impact of Corporate Social Responsibility on National Competitiveness. Journal of Business Ethics, 119, 349-364. http://dx.doi.org/10.1007/s10551-013-1633-2

Carroll, A.B. (1979). A three-dimensional conceptual model of corporate social performance. Academy of Management Review, 4, 497-505.

Carroll, A.B. (1998). The four faces of corporate citizenship. Business and Society Review, 100(1), 1-7. http://dx.doi.org/10.1111/0045-3609.00008

Cornell University, INSEAD, and WIPO (2014). The Global Innovation Index 2014: The Human Factor In innovation, Fontainebleau, Ithaca, and Geneva. Available online in: https://www.globalinnovationindex.org/userfiles/file/reportpdf/GII-2014-v5.pdf

Donaldson, T., \& Preston, L.E. (1995). The stakeholder theory of the corporation: Concepts, evidence, and implications. Academy of Management Review, 20(1), 65-91. http://dx.doi.org/10.5465/AMR.1995.9503271992

Elkington, J. (1997). Cannibals with Forks. The Triple Bottom Line of 21st Century Business. London: New Society Publishers, London.

European Commission (2002). Communication concerning Corporate Social Responsibility of Companies: a contribution for sustainable development. Available online in: http://eurlex.europa.eu/legal-content/EN/ALL/?uri=CELEX:52002DC0347

European Commission (2008). European Competitiveness Report 2008. Luxembourg, European Commission. Available online in: http://bookshop.europa.eu/en/european-competitiveness-report-2008pbNBAK08001/

Fonseca, L. (2012). Influence of Social Responsibility of organisations on theirs Sustainable Success, PhD Thesis, ISCTE-IUL, Lisbon, Portugal. 
Freeman, R.E. (1984). Strategic Management: A Stakeholder Approach. Boston: Pitman.

Gond, J., \& Crane, A. (2010). Corporate social performance disoriented: Saving the lost paradigm?. Business and Society, 49(4), 677-703. http://dx.doi.org/10.1177/0007650308315510

Hall, P.A., \& Soskice, D. (2001). Varieties of capitalism: The institutional foundations of comparative advantage. New York: Oxford University Press.

http://dx.doi.org/10.1093/0199247757.001.0001

Hirsch, P.M., \& Levin, D.Z. (1999). Umbrella advocates versus validity police: A life-cycle model. Organization Science, 10(2), 199-212. http://dx.doi.org/10.1287/orsc.10.2.199

IMD (2014). World Competitiveness Yearbook 2014, IMD World Competitiveness Center. Available online in: http://www.imd.org/news/2014-World-Competitiveness.cfm

ISO, ISO 26000:2010 (2010). Guidance on social responsibility, Geneva, Switzerland: International Organization for Standardization.

MacGillivray, A., Sabapathy, J., \& Zadek, S. (2003). Responsible competitiveness index 2003. London: Accountability and the Copenhagen Centre. Available online in: http://www.accountability.org/images/content/1/0/105/RCI\%202003\%20-\%20Full\%20Report.pdf

Margolis, J.D., \& Walsh, J.P. (2003). Misery loves companies: Rethinking social initiatives by business. Administrative Science Quarterly, 48, 268-305. http://dx.doi.org/10.2307/3556659

McWilliams, A., \& Siegel, D. (2001). Corporate Social Responsibility: A Theory of the Firm Perspective. The Academy of Management Review, 26(1), 117-127.

http://dx.doi.org/10.5465/AMR.2001.4011987

Mitchell, R.K., Agle, B.R., \& Wood, D.J. (1997). Toward a theory of stakeholder identification and salience: defining the principle of who and what really counts. Academy of Management Review, 22(4), 853-886.

Mone, M.A., McKinley, W., \& Barker, V.L. (1998). Organizational decline and innovation: a contingency framework. Academy of Management Review, 23, 115-132.

http://dx.doi.org/10.5465/AMR.1998.192965

OECD/Eurostat (2005). Oslo Manual: Guidelines for Collecting and Interpreting Innovation Data, 3rd Edition, The Measurement of Scientific and Technological Activities, OECD Publishing, Paris. http://dx.doi.org/10.1787/9789264013100-en

Oral, M., \& Chabchoub, H. (1996). On the methodology of the World Competitiveness Report. European Journal of Operational Research, 90(3), 514-535. http://dx.doi.org/10.1016/03772217(94)00370-X 
Orlitzky, M., Schmidt, F.L., \& Rynes, S.L. (2003). Corporate social and financial performance: A meta-analysis. Organization Studies, 24, 403-441. http://dx.doi.org/10.1177/0170840603024003910

Parhankaugas, A., McWilliams, A., \& Shrader, R. (2014). Doing well by doing better: Entrepreneurs and Sustainability. Manuscript submitted for publication.

Pestana, A.H., \& Gajeiro, J.N. (2008). Análise de Dados para as Ciências Sociais-A Complementarida de do SPSS. Lisboa: Edições Silabo.

Penrose, E.T. (1959). The theory of the growth of the firm. Oxford: Oxford University Press.

Porter, M.E., \& Kramer, M.R. (2011). Creating shared value. Harvard Business Review, 89(1/2), 62-77.

Porter, M.E., \& Kramer, M.R. (2006). Strategy and society: The link between competitive advantage and corporate social responsibility. Harvard Business Review, 84(12), 78-92.

Rodríguez, M.M., Gallego, A.C., \& Pérez, B.E. (2014). Responsabilidad Social Corporativa y Rendimiento Financiero: un Meta-Análisis. Spanish Journal of Finance and Accounting / Revista Española de Financiación y Contabilidad, 43(2), 193-215.

http://dx.doi.org/10.1080/02102412.2014.911000

Schwab, K. (2009). The global competitiveness report 2009-2010. Geneva: World Economic Forum. Avalable online in:

http://www.cdc.gob.cl/wp-content/uploads/documentos/reporte_global_de_competitividad_2009_wef.pdf

Schumpeter, J.A. (1942). Capitalism, socialism and democracy. London: Unwin Hyman.

Schwartz, M.S., \& Carroll, A.B. (2003). Corporate Social Responsibility: A Three-Domain Approach. Business Ethics Quarterly, 13(4), 503-530. http://dx.doi.org/10.5840/beq200313435

Stevens, L.K., Neelankavil, J.P., Mendonza, R., \& Shankar, S. (2012). The Economic competitiveness of Countries: A Principal Factors Approach. International Journal of Economics and Finance, 4(12), 76-90. http://dx.doi.org/10.5539/ijef.v4n12p76

United Nation, WECED Report (Brundtland). (1987). Our Common Future. United Nations. Available online in: http://www.un-documents.net/our-common-future.pdf

United Nations (2014). United Nations Development Programme, Human Development Report 2014, United Nations, New York. Available online in: http://hdr.undp.org/sites/default/files/hdr14report-en-1.pdf

van Beurden, P., \& Gossling T. (2008). The Worth of Values - A literature review on the relation between corporate social and financial performance. Journal of Business Ethics, 82(2), 407424. http://dx.doi.org/10.1007/s10551-008-9894-x 
World Economic Forum (2013). Sustainability-Adjusted Global Competitiveness Index (GCI), 2012-2013 edition. Available on line in: http://www.weforum.org/content/pages/sustainablecompetitiveness/

Zadek, S. (2006). Responsible competitiveness: Reshaping global markets through responsible business practices. Corporate Governance, 6, 334-348.

http://dx.doi.org/10.1108/14720700610689469

Journal of Industrial Engineering and Management, 2015 (www.jiem.org)

Article's contents are provided on a Attribution-Non Commercial 3.0 Creative commons license. Readers are allowed to copy, distribute and communicate article's contents, provided the author's and Journal of Industrial Engineering and Management's names are included. It must not be used for commercial purposes. To see the complete license contents, please visit http://creativecommons.org/licenses/by-nc/3.0/. 